EDUKACJA MIĘDZYKULTUROWA

\title{
Oddziaływania socjalizacyjno-wychowawcze dziadków w rodzinie i ich znaczenie w życiu młodych ludzi
}

Streszczenie: Celem opracowania jest zwrócenie uwagi na znaczenie, jakie aktualnie młodzi ludzie przypisują oddziaływaniom socjalizacyjno-wychowawczym dziadków. Głównym obszarem rozważań staje się rodzina jako miejsce międzypokoleniowej transmisji wartości oraz międzypokoleniowych kontaktów. W celu ukazania szczególnego rodzaju kodu kulturowego przekazywanego w środowisku rodzinnym autorka przywołuje fragmenty narracji studentów, zwraca uwagę na fakt, że problematyka stosunków międzypokoleniowych dziadkowie-wnuki, osadzona na pograniczu wielu dyscyplin, jest także przedmiotem zainteresowań edukacji międzykulturowej.

Słowa kluczowe: socjalizacja, wychowanie, dziadkowie, młodzi ludzie, kontakty międzypokoleniowe

\section{Wprowadzenie}

Wobec ukonstytuowanej od wieków wizji rodziny, będącej wciąż jedną z wartości nadrzędnych, oraz w obliczu zagrożeń projektowanych przez codzienność, a dotykających ludzi starszych pragnę zwrócić uwagę na kondycję współczesnej rodziny, relacje, miejsce i znaczenie starszego pokolenia - dziadków w rodzinie.

W artykule zwracam uwagę na postrzeganie rodziny jako obszaru doświadczania więzi międzyludzkich wyrosłych na wizji domu, który gwarantuje nienaruszalność norm i panujących obyczajów, tradycji, ale i postaw wobec drugiego człowieka, form komunikacji z Innymi.

Koncentruję się na relacjach między dziadkami a wnukami. Zarówno młodzi, jak i starsi są dla siebie oparciem w trudnych chwilach, ostoją bezpieczeństwa, przyjaciółmi, partnerami do rozmów, skarbnicą wiedzy. Rola 
babci i dziadka nie jest istotna tylko dla najmłodszych dzieci w rodzinie, dorosłe wnuki również potrzebują i często realnie doceniają obecność swoich dziadków. W związku z tym w artykule podejmuję próbę ukazania roli babci i dziadka w życiu młodych ludzi - studentów.

Celem tego opracowania jest zwrócenie uwagi na znaczenie, jakie obecnie przypisują młodzi ludzie oddziaływaniom socjalizacyjno-wychowawczym dziadków. Głównym obszarem rozważań staje się rodzina jako miejsce międzypokoleniowej transmisji wartości oraz międzypokoleniowych kontaktów.

Dyskurs i ogólna problematyka osób starszych, jakkolwiek przez niektórych separowane w odrębny obszar tematyczny, w gruncie rzeczy osadzone są na pograniczu wielu dyscyplin. Udział w nich mają nauki humanistyczne, społeczne, medyczne czy nawet ekonomiczne. Wśród nich swe uzasadnione miejsce ma pedagogika społeczna, w tym edukacja międzykulturowa. Problematyka rodziny, wartości, międzygeneracyjnej transmisji dziedzictwa kulturowego podejmowana jest od lat w pracach z zakresu edukacji międzykulturowej ${ }^{1}$.

W różnych opracowaniach przewijają się jako poboczne wątki dotyczące m.in. dziadków, stosunków międzypokoleniowych² ${ }^{2}$.

1 Zob. m.in. T. Lewowicki, B. Grabowska (red.): Młodzież i tolerancja. Cieszyn 1998, UŚ - Filia w Cieszynie; T. Lewowicki J. Suchodolska (red.): Rodzina wychowanie wielokulturowość. Cieszyn 2000, UŚ - Filia w Cieszynie; T. Lewowicki, E. Ogrodzka-Mazur, A. Gajdzica (red.): Świat wartości i edukacja międzykulturowa. Cieszyn - Warszawa 2003, UŚ - Filia w Cieszynie, WSP ZNP w Warszawie; J. Nikitorowicz, J. Halicki, J. Muszyńska (red.): Międzygeneracyjna transmisja dziedzictwa kulturowego. Społeczno-kulturowe wymiary przekazu. Białystok 2003, Wydawnictwo Uniwersyteckie „Trans Humana”.

2 Zob. m.in. A. Szczurek-Boruta: Rodzina a tolerancja (z badań młodzieży i rodziców mieszkających na pograniczu polsko-czeskim. W: T. Lewowicki, B. Grabowska (red.): Młodzież i tolerancja. Cieszyn 1998, UŚ - Filia w Cieszynie, s. 99-119; tejże: Oddziaływania socjalizacyjno-wychowawcze $w$ rodzinie w zróżnicowanym środowisku Pogranicza. W: T. Lewowicki J. Suchodolska (red.): Rodzina wychowanie wielokulturowość. Cieszyn 2000, UŚ - Filia w Cieszynie, s. 117-140; tejże: Konflikt czy dialog międzypokoleniowy $w$ rodzinie (studium z pogranicza polsko-czeskiego. W: R. Kwiecińska, M. J. Szymański (red.): Młodzież a dorośli. Napięcia między socjalizacją a wychowaniem. Kraków 2001, AP w Krakowie, s. 322-334; tejże: Partnerzy międzypokoleniowej transmisji dziedzictwa kulturowego. W: J. Nikitorowicz, J. Halicki, J. Muszyńska (red.): Międzygeneracyjna transmisja dziedzictwa kulturowego. Społeczno-kulturowe wymiary przekazu. Białystok 2003, Wydawnictwo Uniwersyteckie „Trans Humana”, s. 73-84; tejże: Edukacja wobec transmisji i transformacji wartości - kilka refleksji dotyczacych 
Podjęta refleksja teoretyczna i przywołane przykłady rodzinnych praktyk społecznych mają istotne walory poznawcze i praktyczne dla edukacji międzykulturowej, której celem jest kreowanie świata bardziej przyjaznego ludziom ${ }^{3}$. Problematyka relacji międzypokoleniowych w rodzinie ze zwróceniem uwagi na osoby starsze ma doniosłe społeczne znaczenie w sytuacji zwiększania udziału populacji osób powyżej 65 lat w ogólnej liczbie ludności Polski, problemów osób starszych, które stają się coraz bardziej widoczne i ważne w dobie kryzysu więzi rodzinnych. Edukacja międzykulturowa powinna umieszczać osoby starsze w polu swych zainteresowań i formułować wskazania dotyczące zmiany w stosunkach międzypokoleniowych; wymiany, zapożyczeń i poprawy jakości funkcjonowania osób starszych i ich adaptacji do dynamicznie zmieniających się warunków społecznych, politycznych i kulturowych.

\section{Badani i przedsięwzięcie badawcze}

W badaniach podjęłam próbę ustalenia odpowiedzi na pytania: Czy i jakie znaczenie przypisują młodzi ludzie oddziaływaniom socjalizacyjno-wycho-

młodzieży z Górnego Śląska. W: T. Lewowicki, E. Ogrodzka-Mazur, A. Gajdzica (red.): Świat wartości i edukacja międzykulturowa. Cieszyn - Warszawa 2003, UŚ - Filia w Cieszynie, WSP ZNP w Warszawie, s. 240-252; Z. Tyszka: Procesy socjalizacji w rodzinie - uwarunkowania makrostrukturalne, mezostrukturalne oraz mikrostrukturalne. W: J. Nikitorowicz: Rodzina wobec wyzwań edukacji międzykulturowej. Białystok 1997, Wydawnictwo Uniwersyteckie Trans Humana, s. 15-28; Z. Gawlin: Teoria rodziny nuklearnej a kondycja wychowawcza rodziny polskiej. W: J. Nikitorowicz: Rodzina wobec wyzwań edukacji międzykulturowej. cyt. wyd., s. 29-39; W. Korzeniowska: Rodzina pośrednikiem międzypokoleniowego przekazu tradycyjnych wartości. W: Rodzina dla Europy czy Europa dla rodziny? Rodina pro Evropu nebo Evropa pro rodinu? T. 2. Dialog bez granic. Dialog bez Hranic. Katowice 2006, Wydział Etnologii i Nauk o Edukacji Uniwersytetu Śląskiego w Cieszynie, Katedra Pedagogiki Nauczania Początkowego i Kształcenia Alternatywnego Uniwersytetu w Ostrawie, s. 141-151; M. Sobecki: Rola rodziców i dziadków w ksztattowaniu poczucia tożsamości Polaków na Białorusi. W: J. Nikitorowicz, J. Halicki, J. Muszyńska: Międzygeneracyjna transmisja dziedzictwa kulturowego. Społeczno-kulturowe wymiary przekazu. cyt. wyd., s. 47-58.

3 Zob. m.in. T. Lewowicki, E. Ogrodzka-Mazur, A. Szczurek-Boruta (red.): Edukacja międzykulturowa w Polce i na świecie. Katowice 2000, UŚ; J. Nikitorowicz: Kreowanie tożsamości dziecka. Wyzwania edukacji międzykulturowej. Gdańsk 2005, GWP; J. Nikitorowicz: Edukacja regionalna i międzykulturowa. Warszawa 2009, WAiP; J. Nikitorowicz: Edukacja międzykulturowa w kręgu potrzeb, oczekiwań $i$ stereotypów. Białystok 1995, Wydawnictwo Uniwersyteckie „Trans Humana”. 
wawczym dziadków w rodzinie? Czy i w jaki sposób dziadkowie warunkują proces socjalizacyjno-wychowawczy młodych ludzi?

Stawiam tezę, że dziadkowie odegrali i nadal odgrywają znaczącą rolę w procesie socjalizacyjno-wychowawczym młodych ludzi.

Prezentowane niżej wyniki są efektem badania pilotażowego poprzedzającego zakrojone na większą skalę przedsięwzięcie badawcze. Badania przeprowadzono w grupie 12 osób, w wieku 22-23 lat, studentek kierunku pedagogika Wydziału Nauk o Edukacji i Etnologii w Cieszynie Uniwersytetu Śląskiego w Katowicach. Studenci stali się narratorami opowiadającymi o swoich relacjach z dziadkami.

Zastosowałam strategię jakościową ${ }^{4}$, metodę wywiadu, technikę wywiadu narracyjnego ${ }^{5}$. „Wywiad narracyjny dostarcza znacznie obszerniejszego materiału niż ten, z którego badacz jest w stanie skorzystać. Chodzi o to, aby badane zmienne ujrzeć w szerszym tle, w kontekstach, które im towarzyszyły"6.

\section{Oddziaływania socjalizacyjno-wychowawcze dziadków w życiu młodych ludzi - narracje studentów}

W rodzinie dziecko stawia pierwsze kroki, zarówno w przestrzeni fizycznej, jak i symbolicznej. Wspólnota rodzinna stanowi najważniejszą przestrzeń, w której żyje człowiek, uczestnicząc w jej przetrwaniu, zachowaniu ciągłości i rozwoju. Jakiego rodzaju jest to uczestnictwo w życiu dorosłym, zależy właśnie od pierwszych lat życia spędzonych w gronie najbliższych ${ }^{7}$. To za przyczyną rodziców i dziadków dziecko zostaje łagodnie wprowadzone w kod kulturowy pozwalający mu na komunikację z innymi ludźmi, ale także na odczuwanie wspólnoty i w ten sposób realizację jednej z podstawowych ludzkich potrzeb.

4 T. Bauman: Strategie jakościowe w badaniach pedagogicznych. W: T. Pilch, T. Bauman: Zasady badań pedagogicznych. Strategie ilościowe i jakościowe. Warszawa 2001, „Żak”; J. Krajewski, T. Lewowicki, J. Nikitorowicz (red.): Problemy wspótczesnej metodologii. Olecko 2001, Wszechnica Mazurska w Olecku; K. Rubacha: Metody zbierania danych w badaniach pedagogicznych. W: Z. Kwieciński, B. Śliwerski (red.): Pedagogika. Podręcznik akademicki. T. 1. Warszawa 2003, PWN.

5 D. Urbaniak-Zając, J. Piekarski (red.): Jakościowe orientacje w badaniach pedagogicznych. Studia i materiaty. Łódź 2001, Wyd. UŁ.

6 K. Rubacha: Metodologia badań nad edukacja. Warszawa 2008, WAiP, s. 136.

7 J. Nikitorowicz: Szanse i zagrożenia tożsamości rodzinnej. W: J. Nikitorowicz (red.): Rodzina wobec wyzwań w edukacji międzykulturowej. Białystok 1999, Wydawnictwo Uniwersyteckie „Trans Humana”. 
Tak rozumiana rodzina kształtuje i rozwija w dziecku nie tylko poczucie tożsamości dziedziczonej ${ }^{8}$, które narasta wraz z interioryzacją zachowań, postaw społecznych i wartości, możliwą dzięki emocjonalnym wymiarom kontaktów międzyludzkich w małej grupie, ale przede wszystkim wprowadza je w proces nabywania tożsamości osobowej, społecznej drogą twórczej akceptacji siebie i wymagającej od jednostki dojrzałości wyboru i poczucia własnej adekwatności ${ }^{9}$. Rozumienie tego pojęcia jest związane z samoświadomością jednostki, świadomością emocjonalną i społeczną przynależnością do grupy, a także potrzebą funkcjonowania w jej obrębie.

Świadomie dokonywany wybór tożsamości jest efektem mediacji między naturą - dziedziczeniem a kulturą, na co zwraca uwagę J. Nikitorowicz ${ }^{10}$.

Rodzenie się tożsamości w aspekcie samoświadomości ma miejsce w procesie socjalizacji. Socjalizację pojmuję jako „ogół procesów nabywania pod wpływem otoczenia społecznego dyspozycji psychicznych czyniących jednostkę zdolną do życia w społeczeństwie cywilizowanym. Kształtuje ona osobowość człowieka i przygotowuje go do życia w zbiorowości, umożliwia porozumiewanie się i inteligentne działanie w jej ramach, uczy, jak się zachowywać, by osiągnąć cele życiowe"11.

Środowisko, w którym żyje jednostka, to przede wszystkim środowisko wychowawcze $-\mathrm{w}$ nim dokonuje się jej socjalizacja ${ }^{12}$. Przedmiotem badań i analiz są często uwarunkowania procesu socjalizacji, a także jej szczegółowych aspektów, na przykład międzypokoleniowej transmisji wartości dokonującej się w środowisku rodzinnym ${ }^{13}$. Robert Merton twierdzi, że „rodzina

8 Por. J. Nikitorowicz: Szanse i zagrożenia tożsamości rodzinnej na pograniczu kultur. W: J. Nikitorowicz (red.): Rodzina wobec wyzwań edukacji międzykulturowej. Białystok 1997, Wydawnictwo Uniwersyteckie „Trans Humana”, s. 68.

9 Interpretacji tak rozumianej koncepcji opracowanej przez Eriksona dokonuje L. Witkowski: Rozwój i tożsamość w cyklu życia. Studium koncepcji E. H. Eriksona. Toruń 1989, UMK, s. 30.

10 Por. J. Nikitorowicz: Szanse i zagrożenia tożsamości rodzinnej na pograniczu kultur. W: J. Nikitorowicz (red.): Rodzina wobec wyzwań edukacji międzykulturowej. cyt. wyd., s. 70

11 J. Szczepański: Elementarne pojęcia socjologii. Warszawa 1970, PWN, s. 94.

12 Szerokie omówienie zagadnienia socjalizacji w ujęciu różnych teorii - przede wszystkim psychologicznych i socjologicznych można znaleźć między innym w pracy K. J. Tillmann: Teorie socjalizacji. Spoteczność-instytucja-upodmiotowienie. Warszawa 1996, PWN.

13 J. Piekarski: Międzypokoleniowa transmisja wartości w środowisku rodzinnym 
jest najważniejszym pasem transmisyjnym, służącym przekazywaniu wzorców kulturowych następnemu pokoleniu"14.

W wyniku socjalizacji pierwotnej dziecko przejmuje role i postawy dorosłych, czyli internalizuje je i czyni swoimi. „Internalizacja jest podstawą - po pierwsze rozumienia innych ludzi oraz po drugie, postrzegania świata jako rzeczywistości znaczącej i jako rzeczywistości społecznej”"

Człowiek zostaje poddany socjalizacji w swoim najbliższym środowisku rodzinnym - mowa wówczas o socjalizacji pierwotnej - oraz socjalizacji w środowisku lokalnym.

Peter Ludwig Berger i Thomas Luckman twierdzą, że dla jednostki „ważniejsza jest socjalizacja pierwotna oraz, że zasadnicza struktura jakiejkolwiek socjalizacji wtórnej musi przypominać strukturę tej pierwszej"16.

Babcia oraz dziadek pełnią w rodzinie różne funkcje - na uwagę zasługuje funkcja socjalizacyjno-kulturotwórcza, jakość doświadczeń i interakcji pomiędzy pokoleniami wpływa na budowanie przez dziecko rozległej wiedzy osobistej na temat stosunków społecznych.

Wśród pozostałych funkcji wypełnianych w rodzinie przez dziadków wymienić należy funkcję opiekuńczo-wychowawczą oraz ekonomiczno-materialną i poznawczą ${ }^{17}$.

Realizacja wymienionych funkcji znajduje odzwierciedlenie w narracjach badanych. Świadczy o tym poniższa wypowiedź.

Nie wyobrażam sobie na chwile obecna mieszkać bez dziadków, gdyż bez ich wsparcia emocjonalnego i spokojnego podejścia mogłabym nie dać sobie rady z problemami. Sa dla mnie oparciem również pod względem finansowym $^{18}$ (Ilona) ${ }^{19}$.

matego miasta. Wychowawcze studium relacji międzygeneracyjnych. Łódź 1992, Uniwersytet Łódzki; T. Rostowska: Transmisja międzypokoleniowa $w$ rodzinie $w$ zakresie wybranych wymiarów osobowości. Łódź 1995, Uniwersytet Łódzki.

14 R. K. Merton: Teoria socjologiczna i struktura społeczna. Warszawa 1982, PWN, s. 221-222.

15 P. L. Berger, T. Luckmann: Społeczne tworzenie rzeczywistości. Warszawa 1983, PIW, s. 203.

16 Tamże, s. 9.

17 J. Andrzejewska: Spotkania dzieci i seniorów. „Wychowanie w Przedszkolu” 2006, nr 4, s. 5.

18 Fragmenty wypowiedzi studentów zaznaczone zostały kursywą.

19 Imiona studentów zostały zmienione na potrzeby artykułu. 
W środowisku rodzinnym zdobywa się umiejętności współdziałania oraz czerpie elementy kultury i świata wartości, „dokonuje się proces enkulturacji dziecka, czyli wprowadzania go do kultury społeczeństwa, w którym będzie żyło"20.

Jak twierdzi Teresa Kukołowicz, „dziadkowie kształtują u wnuków ich tożsamość rodzinną, regionalną i narodową, przekazują historię swego życia, podtrzymują kulturę wyrażającą się w pewnych prawdach życiowych, przyczyniają się do zachowania różnych obyczajów w rodzinie, są ośrodkiem rodzinnej informacji, a także moralnego i materialnego oparcia oraz pomocy dzieciom i wnukom"21.

Rodzina stanowi najważniejsze środowisko wychowawcze, przygotowuje najmłodsze pokolenie do życia w określonym środowisku, systemie ról i wartości.

W wypowiedziach studentów czytamy:

Dziadkowie sa dla mnie wzorem do naśladowania, żywa historia, skarbnica tradycji związanych ze świętami. Babcia od dziecka powtarza mi, że o zwyczaje trzeba dbać (Martyna).

Dziadkowie sq dla mnie ogromnym autorytetem $w$ kwestii tradycji $i$ szeroko pojętego regionalizmu, zawdzięczam im także mocne poczucie własnej tożsamości $i$ wiedzę o tym kim jestem, jaka jestem, jaka jest historia mojej rodziny. Duże znaczenie ma dla mnie także to, że dzięki dziadkowi, a właściwie, dzięki temu skad pochodzi wyksztatcita sie jedna $z$ moich pasji. W mojej rodzinie dziadkowie od zawsze byli ludźmi dużej rangi, którym należat sie szacunek, ale i na których zawsze można byto liczyć, byli i sq starszyzna, której mądrość pozwalata nie popetniać wielu życiowych błędów (Iwona).

Dziadkowie są dla swoich wnucząt nie tylko przekazicielami tradycji ${ }^{22}$, ale również codziennej wiedzy. Przekazują z pokolenia na pokolenia obyczaje,

20 A. Twardowski: Rodzina jako środowisko edukacyjno-kulturowe. W: D. Jankowski (red.): Edukacja kulturalna. Szkoła i rodzina. Kalisz 1993, Wojewódzki Ośrodek Metodyczny w Kaliszu, s. 41.

21 T. Kukołowicz: Jakim wartościom poświęca się wspótczesny stary człowiek. W: S. Steuden, M. Marczuk (red.): Starzenie się a satysfakcja z życia. Lublin 2006, Wydawnictwo KUL, s. 199.

22 Tradycja rozumiana jest jako „przekazywanie z pokolenia na pokolenia obyczajów, zwyczajów, obrzędów, a także przekonań, zasad, wierzeń, sposobów myślenia, odczuwania lub postępowania, wydarzeń z przeszłości, traktowanych jako historyczne, choć niesprawdzalnych umiejętności artystycznych albo rzemieślniczych". Zob.: J. Szymik: Ludowe obrzędy zwyczaje doroczne Lachów Cieszyńskich. W: M. G. Gerlich, D. K. Kadłubiec: Zaolzie: studia i materiały z dziejów społeczności polskiej w Czechosłowacji. Katowice 1992, Społeczne Centrum Badań Nauk i Dokumentacji, s. 61. 
zwyczaje, obrzędy, przekonania, zasady, wierzenia, sposoby myślenia, odczuwania lub postępowania.

Współcześnie częstymi sytuacjami są również takie, kiedy to wnuki są dla swoich dziadków nauczycielami. „Są takie dziedziny wiedzy, kiedy to wnuki mają do spełnienia szereg zadań edukacyjnych wobec starszych pokoleń - nie tylko dziadków, lecz także rodziców. W relacjach babcia (dziadek)/wnuk (podopieczny) transfer wiedzy jest dwukierunkowy. Z całą pewnością to dziadkowie przekazują wnukom unikalne dziedzictwo historyczne, obyczajowe, ale również emocjonalne, w zasadzie niemożliwe do bezpośredniego doświadczenia w żaden inny sposób. Jednak obecnie dzieci mają bardzo łatwy dostęp do wiedzy (telewizja, Internet, bogato ilustrowane publikacje popularnonaukowe) i niejednokrotnie stanowią dla starszych osób źródło inspiracji do ubogacania własnych wiadomości"23. Najczęściej młode pokolenie staje się dla starszego źródłem inspiracji w dziedzinie techniki oraz informatyki.

W jednej z narracji czytamy:

Moi dziadkowie, z jednej strony sq tradycyjni - opiekują się wnukami, pilnuja tradycji, czasem powspominaja dawne czasy. Oczywiście sa bezwarunkowo zakochani w wnukach. Z drugiej strony jednak, sq nowocześni - sq aktywni społecznie, a także fizycznie, sa na bieżaco z trendami, podoba im się moda młodzieżowa, nawet nas do niej zachęcaja (Brygida).

Przekazywanie elementów kultury, tradycji, obrzędów, obyczajów przez dziadków młodszemu pokoleniu, uzależnione jest w dużej mierze od relacji panujących między tymi osobami. „Stosunki między dziadkami a wnukami zależą od: częstotliwości i charakteru kontaktów; linii pokrewieństwa; wieku wnuków; wieku i stanu zdrowia dziadków; społecznych tradycji, norm i oczekiwań odnoszących się do pozycji i różnych ról rodzinnych"24.

Charakter kontaktów ma duże znaczenie dla poprawności relacji między dziadkami a wnukami. Częstotliwość kontaktów uzależniona jest od miejsca zamieszkania, ale mogą na nią mieć również wpływ relacje między dziadkami a ich dziećmi, stan zdrowia oraz wiek dziadków. Ważne są również normy oraz zasady wpajane dzieciom przez ich rodziców, stosunek do dziadków

23 A. Stefaniak-Hrycko: Międzypokoleniowy transfer wiedzy. W: A. Fabiś, M. Muszyński (red.): Społeczne wymiary starzenia się. Bielsko-Biała 2011, Stowarzyszenie Gerontologów Społecznych i Wyższa Szkoła Administracji w Bielsku-Białej, s. 40.

24 B. Grzeszkiewicz: Dziadkowie w życiu dziecka. W: B. Bugajska (red.): Młodość i starość integracja pokoleń. Szczecin 2010, ZAPOL, s. 122. 
kształtowany jest u wnucząt na podstawie opinii wyrażanych przez rodziców oraz relacji między dziadkami i ich dziećmi.

Prawidłowe relacje między dziadkami i wnukami przyczyniają się do rozwoju u tych podmiotów poczucia bezpieczeństwa, wzajemnego szacunku oraz zaufania.

„Podkreślić należy, że dla wielu starszych osób rodzina (dzieci i wnukowie) stanowi źródło siły, wsparcia, daje motywację do działań, zajmuje istotne miejsce w ich życiu. Prawidłowe relacje rodzinne w okresie wczesnej, a także późnej starości stanowią dla osób starzejących się i starszych podstawę ich prawidłowego funkcjonowania. Pomagają pomyślnie przejść okres adaptacji do życia na emeryturze odnaleźć swoje miejsce w nowej rzeczywistości, odkryć nowe obszary aktywności, także na płaszczyźnie życia rodzinnego"25.

Maria Susułowska podaje w tej kwestii interesujące stwierdzenie badacza tej problematyki, a mianowicie, iż „dziadkowanie jest rodzicielstwem trochę przesuniętym w czasie, uwolnionym jednak od stresów macierzyństwa i odpowiedzialności ojcostwa"26.

Na uwagę zasługuje fakt, że realne istnienie babci lub dziadka w rodzinie przyczynia się do zdobywania i pogłębiania wiedzy na temat starości i osób starszych przez młodsze pokolenie. „Sama obecność osób starszych w rodzinie uczy młodsze pokolenia o starzeniu się i starości"27.

Świadczy o tym wypowiedź jednej ze studentek, która na podstawie dystansu zaistniałego między nią a jej dziadkami stwierdza, że starość jest jej obca.

Zacznę od tego, że nigdy nie taczyty mnie szczególnie mocne więzi z własnymi dziadkami. Nie mam jakichś cieptych wspomnień z dzieciństwa zwiqzanych z własnymi dziadkami. Obce jest mi pieczenie ciasta światecznego $z$ babcia, siadanie dziadkowi na kolana i stuchanie opowieści. Nigdy nie bytam ulubionq wnusiq swoich dziadków - ktoś mógłby powiedzieć, że może oni mieli takie charaktery, bardziej okazywali uczucia najstarszym dzieciom swoich dzieci. Do nas - młodszych wnuczat odnosili się z rezerwa i dystansem.

25 B. Zięba-Kołodziej: Rola dziadków w życiu rodziny. W: D. Seredyńska (red.): Uczestnictwo społeczne w średniej i późnej dorosłości. Bydgoszcz 2012, Wydawnictwo Uniwersytetu Kazimierza Wielkiego, s. 139.

26 A. Leszczyńska-Rejchert: Człowiek starszy i jego wspomaganie - w stronę pedagogiki starości. Olsztyn 2010, Wydawnictwo Uniwersytetu Warmińsko-Mazurskiego w Olsztynie, s. 62-63.

27 Tamże. 
Przez takie relacje między mna a moimi dziadkami starość byta i nadal jest dla mnie obca (Magdalena).

Jak zauważa Małgorzata Halicka, „stosunek do wnuków zależy nie tylko od cech indywidualnych osoby, ale także od obowiązujących w danej społeczności norm kulturowych"28.

Dziadkowie chcą mieć - i są przekonani, że mają - wpływ na podejmowane przez wnuki decyzje, dokonywane w życiu wybory. Czują się potrzebni, kiedy mogą pozostać w stałych kontaktach ze swoimi najbliższymi, uczestniczyć w realizacji ich planów na przyszłość. „Dzieciństwo z dziadkami wpływa na to, jak wnuki jako dorośli będą postępować w stosunku do własnych wnuków"29.

Relacje między dziadkami a wnukami obalają często mity i stereotypy panujące w społeczeństwie na temat starości. Zacieśnia to relację między młodszym i starszym pokoleniem, stwarza sytuację, w której człowiek starszy nie musi być nieudolny, schorowany czy zależny od osób trzecich. Przedstawia pokolenie osób w późnej dorosłości jako to, które jest w stanie wiele zaoferować swoim wnukom. Wnuki wprowadzają swoich dziadków w świat nowinek technicznych, natomiast dziadkowie są źródłem doświadczenia i mądrości życiowej.

Taki wizerunek babci opisany został w kolejnej narracji:

W moim życiu jest jedna osoba, która zmienia stereotyp starszego człowieka. Jest niq moja babcia, która nie pasuje do typowego wizerunku osób starszych w naszym społeczeństwie. Jest osobq o wielkim sercu. Wiele razy udowadniała w swoim życiu, że liczy się dla niej coś więcej niż tylko pieniqdze. W catym jej życiu zdarzyto się wiele sytuacji, w których pokazata, że jest dobrym człowiekiem oraz osoba, na która zawsze można liczyć. Mimo swojego wieku jest bardzo energiczna i pozytywnie nastawiona do życia, co odróżnia ją od wielu osób często nawet młodszych, które pomimo lepszego zdrowia i lepszej sytuacji materialnej nie potrafia cieszyć się tym co mają (Karina).

Elżbieta Bojanowska twierdzi, że: „wzajemna pomoc i współzależność pokoleń w rodzinie jest najlepszym rozwiązaniem, zarówno dla osób starszych, jak i dla dzieci. Aby człowiek stary był nie tylko przedmiotem troski i opieki, ale cennym źródłem doświadczania i mądrości życiowej" ${ }^{30}$.

28 M. Halicka: Satysfakcja życiowa ludzi starych. Białystok 2004, Akademia Medyczna w Białymstoku, s. 285.

29 A. I. Brzezińska, K. Ober-Łopatka, R. Stec, K. Ziółkowska: Szanse rozwoju w okresie późnej dorostości. Poznań 2007, Wydawnictwo Fundacji Humaniora, s. 87.

30 E. Bojanowska: Opieka nad ludźmi starszymi. W: P. Szukalski (red.): To idzie 
Szczególną uwagę należy zwrócić na obustronną zależność między dziadkami i wnukami, wzajemna pomoc i życzliwość jest istotna w prawidłowych relacjach między młodszym i starszym pokoleniem. Na pozytywne relacje między tymi osobami ma wpływ zaakceptowanie wzajemnej zależności, istotne jest, aby wnukowie zaakceptowali wkład swoich dziadków w opiekę oraz przekazywanie wiedzy. Natomiast przed dziadkami stoi zadanie pogodzenia się z zależnością od wnuków, zarówno pod względem opieki, jak również edukacji. Spojrzenia na swoje wnuki jako drogowskazy wprowadzające starsze pokolenie w nowoczesny świat.

Dla wielu starszych osób świadomość bycia potrzebnym swojej rodzinie, mimo zaawansowanego wieku, daje im motywację i siłę do dalszego działania.

Moja babcię „napędza” do działania świadomość, że jest komuś potrzebna, że może mi ugotować obiad, upiec ciasto i zawsze będzie to radosnym dla mnie wydarzeniem. Wie, że sprawi tym radość komuś i przy okazji sobie (Michalina).

Zaznaczyć należy, że pozytywne relacje między wnukami i dziadkami są istotne zarówno dla młodszego, jak i starszego pokolenia. Wnuki dla osób starszych są źródłem radości oraz motywują do aktywnego spędzania czasu wolnego. „Faktem jest bowiem, iż wnuki przyczyniają się zarówno do procesu socjalizacji, jak też są istotnym źródłem wsparcia i pozytywnych emocji dla swoich dziadków"31. Kwestia ta znalazła wyraz w następującej wypowiedzi.

Mam cudownych kochajacych dziadków, którzy zawsze chętnie stuża pomoca mnie oraz moim rodzicom. Wiem, że w razie jakiegokolwiek problemu moge się do nich zwrócić. Dziadek pomaga moim rodzicom odwożac i przywożac moje młodsze rodzeństwo ze szkoty. Jest również nasza złotą raczką. Jesteśmy mu za to bardzo wdzięczni, a on cieszy się, że może pomóc, $i$ że jest komuś potrzebny. Babcia natomiast gotuje pyszne obiady dla całej naszej rodziny (Sylwia).

Współcześni dziadkowie oraz babcie są i byli dla swoich wnucząt (badanych studentów) oparciem oraz skarbnicą wiedzy. Dysponując większą ilością czasu niż pracujący rodzice, jako pierwsi wpajają swoim wnukom wartości oraz normy, którymi powinni kierować się w życiu.

starość. Postawy osób w wieku przedemerytalnym. Warszawa 2009, Raport z badań ZUS, s. 211.

31 A. Klatkiewicz: Integracja pokoleń $w$ aspekcie dobrostanu społecznego ludzi starszych. W: B. Bugajska (red.): Młodość i starość integracja pokoleń. Szczecin 2010, ZAPOL, s. 57. 
Fakt ten jest podkreślany w literaturze przedmiotu. „Tam gdzie kontakt wnuków z dziadkami jest bliski, to oni właśnie, bardziej niż rodzice pełnią wobec wnuków rolę socjalizacji pierwotnej. To starsze pokolenie opisuje i przedstawia świat w szerszym kontekście, podczas gdy rodzice (będący partnerami i przyjaciółmi) uczą się razem ze swoimi dziećmi współczesności, dziadkowie odgrywają rolę »mędrców życia «, stanowią bezpieczną bazę orientacyjną [...] To dziadkowie funkcjonują jako »bastiony bezpieczeństwa« w tym do końca niejasnym, chaotycznym i niepewnym pluralistycznym świecie możliwości i zagrożeń” ${ }^{32}$.

Przez wielu studentów dziadkowie postrzegani są jako autorytety w dziedzinie edukacji, zadaniem studentów to dziadkowie byli często pierwszymi nauczycielami, którzy przekazywali im wiedzę, normy oraz zasady, którymi powinni kierować się w życiu.

Potwierdzeniem tych słów są poniższe wypowiedzi studentek.

Zawdzięczam swoim dziadkom wychowywanie, uczenie dobrych manier i zachowania, czasem nawet zastępowali mi rodziców (Jolanta).

Przez wszystkie lata dziadkowie byli przy mnie, opiekowali się mna, wychowywali i uczyli jak być dobrym człowiekiem. Sa dla mnie najważniejsi. Mam ogromne wyrzuty sumienia, że nie moge im teraz poświęcić tyle czasu, ile Oni poświęcili dla mnie. Gdyby nie Oni, bytabym zupełnie innym człowiekiem (Ilona).

W procesie socjalizacji dziadkowie czują się odpowiedzialni za kształtowanie hierarchii wartości swoich wnuków. Osoby starsze, wprowadzając młodsze pokolenia w swoisty kod kulturowy, szczególną uwagę zwracają na przekazywanie zasad moralnych, stając się tym samym dla młodych autorytetem.

Moja nieżyjąca - już od dziesięciu lat babcia byta dla nie prawdziwym autorytetem. Byta osoba, która pielegnowała we mnie wiare i była przyktadem człowieka postępujacego zgodnie z jej regułami. Babcia byta osoba, u której spędzałam czas po zajęciach $w$ szkole czekajac na rodziców, aż wróca z pracy. Była moja opiekunką do momentu powrotu rodziców z pracy (Małgorzata).

Dla badanych studentów babcia i dziadek to również osoby, które jednoczą rodzinę. Są osobami, które dbają o przekazywanie i kultywowanie tradycji rodzinnych, często wokół własnej osoby skupiają resztę rodziny przy niedzielnym lub wigilijnym stole.

32 H. Świda-Ziemba: Młodzież końca tysiąclecia. Obszar świata i bycia w świecie. Warszawa 2000, ISNS UW, s. 155-159. 
Dom mojej babci stanowi swego rodzaju centrum spotkań mojej licznej rodziny, gdzie zawsze jest czas, żeby usiąść i porozmawiać (Klaudia).

Opowieści rodzinne stanowią punkt odniesienia do sytuacji społecznych, są jednym z czynników transmisji międzypokoleniowej w ramach, której starsze pokolenia kształtują hierarchę wartości młodszych pokoleń. Badani studenci w swoich wypowiedziach podkreślali istotną rolę rozmów międzypokoleniowych.

\section{Konkluzje}

Przytoczone fragmenty narracji potwierdziły postawioną tezę, że dziadkowie odegrali bądź nadal odgrywają znaczącą rolę w procesie socjalizacyjno-wychowawczym młodych ludzi.

Osoby starsze jako członkowie rodziny biorą aktywny udział w socjalizacji pierwotnej, przekazują wiedzę, system norm i wartości.

Jak wynika z wypowiedzi studentów, babcia i dziadek to osoby zazwyczaj postrzegane pozytywnie. Są skarbnicą wiedzy oraz mądrości. Ich spokój oraz opanowanie dają młodym ludziom poczucie bezpieczeństwa i życiowej harmonii. Studenci cenią sobie wspólnie spędzony czas ze swoimi dziadkami.

Dziadkowie w życiu badanych odegrali bądź nadal odgrywają istotną rolę. Studenci podkreślali udział dziadków w wychowaniu, w przekazywaniu tradycji, wartości, w kształtowaniu postaw.

Pozytywne relacje między dziadkami i wnukami przyczyniają się do prawidłowego funkcjonowania całej rodziny. Łatwiej wówczas borykać się z codziennymi problemami, kiedy wśród bliskiej rodziny możemy znaleźć ciepło, spokój oraz wsparcie. Życzliwość, ze strony najbliższych - dziadków, rodziców, dzieci, wnuków - daje wszystkim członkom rodziny bezpieczeństwo. Osoby starsze motywuje do działania, pozwala czuć się potrzebnymi, postępuje proces integracji ich tożsamości. Często tak się dzieje, że rady oraz sugestie babć oraz dziadków ludzie doceniają i wprowadzają w życie po czasie. Zbyt późno, aby naprawić popełnione błędy i zbyt późno, aby im podziękować.

Przed pedagogiką stają obecnie nowe wyzwania tworzenia sprzyjających warunków rozwoju osobistego, aktywności fizycznej i intelektualnej osób starszych. Problem relacji międzypokoleniowej oraz udział dziadków w procesie socjalizacyjno-wychowawczym zasługuje na zainteresowanie także na gruncie edukacji międzykulturowej z uwagi na potrzebę budowania nowego 
K. JAS $\$$ ODDZIAŁYWANIA SOCJALIZACYJNO-WYCHOWAWCZE...

spojrzenia na proces starzenia się, kształtowania (się) tożsamości osób starszych oraz dostrzegania ich pozycji w nowej rzeczywistości rodzinnej.

\section{Bibliografia}

Andrzejewska J.: Spotkania dzieci i seniorów. „Wychowanie w Przedszkolu” 2006, nr 4.

Berger P.L ., Luckmann T.: Społeczne tworzenie rzeczywistości. Warszawa 1983, PIW.

Brzezińska A. I., Ober-Łopatka K., Stec R., Ziółkowska K.: Szanse rozwoju w okresie późnej dorosłości. Poznań 2007, Wydawnictwo Fundacji „Humaniora".

Bugajska B. (red.): Młodość i starość integracja pokoleń. Szczecin 2010, ZAPOL.

Fabiś A., Muszyński M. (red.): Społeczne wymiary starzenia się. Bielsko-Biała 2011, Stowarzyszenie Gerontologów Społecznych i Wyższa Szkoła Administracji w Bielsku-Białej.

Gerlich M. G., Kadłubiec D. K.: Zaolzie: studia i materiały z dziejów spoŁeczności polskiej w Czechosłowacji. Katowice 1992, Społeczne Centrum Badań Nauk i Dokumentacji.

Halicka M: Satysfakcja życiowa ludzi starych. Białystok 2004, Akademia Medyczna w Białymstoku.

Jankowski D. (red.): Edukacja kulturalna. Szkoła i rodzina. Kalisz 1993, Wojewódzki Ośrodek Metodyczny w Kaliszu.

Krajewski J.: Problemy wspótczesnej metodologii. Olecko 2001, Wszechnica Mazurska w Olecku.

Kwiecińska R., Szymański M. J. (red.): Młodzież a dorośli. Napięcia między socjalizacją a wychowaniem. Kraków 2001, AP w Krakowie.

Kwieciński Z., Śliwerski B. (red.): Pedagogika. Podręcznik akademicki. T. 1. Warszawa 2003, PWN.

Leszczyńska-Rejchert A.: Człowiek starszy i jego wspomaganie - w stronę pedagogiki starości. Olsztyn 2010, Wydawnictwo Uniwersytetu Warmińsko-Mazurskiego w Olsztynie.

Lewowicki T. Suchodolska J. (red.): Rodzina, wychowanie, wielokulturowość. Cieszyn 2000, UŚ - Filia w Cieszynie. 
Lewowicki T., Grabowska B. (red.): Młodzież i tolerancja. Cieszyn 1998, UŚ - Filia w Cieszynie.

Lewowicki T., Ogrodzka-Mazur E., Gajdzica A. (red.): Świat wartości i edukacja międzykulturowa. Cieszyn - Warszawa 2003, UŚ - Filia w Cieszynie, WSP ZNP.

Merton R.K.: Teoria socjologiczna i struktura społeczna. Warszawa 1982, PWN.

Nikitorowicz J. (red.): Rodzina wobec wyzwań w edukacji międzykulturowej. Białystok 1999, Wydawnictwo Uniwersyteckie „Trans Humana”.

Nikitorowicz J., Halicki J., Muszyńska J. (red.): Międzygeneracyjna transmisja dziedzictwa kulturowego. Społeczno-kulturowe wymiary przekazu. Białystok 2003, Wydawnictwo Uniwersyteckie „Trans Humana”.

Nikitorowicz J.: Edukacja regionalna i międzykulturowa. Warszawa 2009, WAiP.

Nikitorowicz J.: Edukacja międzykulturowa w kręgu potrzeb, oczekiwań $i$ stereotypów. Białystok 1995, Wydawnictwo Uniwersyteckie „Trans Humana”.

Nikitorowicz J.: Kreowanie tożsamości dziecka. Wyzwania edukacji międzykulturowej. Gdańsk 2005, GWP.

Nikitorowicz J.: Rodzina wobec wyzwań edukacji międzykulturowej. Białystok 1997, Wydawnictwo Uniwersyteckie „Trans Humana”.

Piekarski J.: Międzypokoleniowa transmisja wartości w środowisku rodzinnym małego miasta. Wychowawcze studium relacji międzygeneracyjnych. Łódź 1992, Uniwersytet Łódzki.

Pilch T., Bauman T.: Zasady badań pedagogicznych. Strategie ilościowe i jakościowe. Warszawa 2001, „Żak”.

Rostowska T.: Transmisja międzypokoleniowa $w$ rodzinie $w$ zakresie wybranych wymiarów osobowości. Łódź 1995, UŁ.

Rubacha K.: Metodologia badań nad edukacją. Warszawa 2008, WAiP.

Seredyńska D. (red.): Uczestnictwo społeczne w średniej i późnej dorostości. Bydgoszcz 2012, UKW.

Steuden S., Marczuk M. (red.): Starzenie się a satysfakcja z życia. Lublin 2006, KUL.

Szczepański J.: Elementarne pojęcia socjologii. Warszawa 1970, PWN.

Szukalski P. (red.): To idzie starość. Postawy osób w wieku przedemerytalnym. Warszawa 2009, Raport z badań ZUS.

Świda-Ziemba H.: Młodzież końca tysiąclecia. Obszar świata i bycia w świecie. Warszawa 2000, ISNS UW. 
Tillmann K. J.: Teorie socjalizacji. Społeczność - instytucja - upodmiotowienie. Warszawa 1996, PWN.

Urbaniak-Zając D., Piekarski J. (red.): Jakościowe orientacje w badaniach pedagogicznych. Studia i materiaty. Łódź 2001, UŁ.

Witkowski L.: Rozwój i tożsamość w cyklu życia. Studium koncepcji E. H. Eriksona. Toruń 1989, UMK.

\section{Socializing and educational influences of grandparents in the family and their significance in the young's life}

\section{Summary}

The aim of this study is taking notice of a meaning which is currently attributed by young people to socialising and pedagogical influence of their grandparents. The main area of consideration is the family as a location of intergenerational transmission of values and intergenerational contacts. In order to show a particular type of cultural code transferred in the family environment, the author brings extracts of student narration, takes notice of a fact that issues of intergenerational relations grandparents - grandchildren settled on borderland of numerous disciplines, is an object of interest for intercultural education.

Key words: socialization, education, grandparents, young people, intergenerational contacts 